\title{
Hemşirelik Öğrencilerinin Akademik Başarısı ile Stres ve Bilişsel Esneklik İlişkisinin Belirlenmesi
}

\section{The Relationship Between Nursing Students' Academic Achievement and Stress and Cognitive Flexibility}

\author{
Neşe Uysal ${ }^{1}$ (iD) Filiz Ünal Toprak ${ }^{2}$ (iD \\ ${ }^{1}$ Amasya Üniversitesi Sağlık Bilimleri Fakültesi, İpekköy, Amasya, TÜRKIYE \\ ${ }^{2}$ Bolu Abant İzzet Baysal Üniversitesi Sağlık Bilimleri Fakültesi, Bolu, TÜRKiYY \\ Gelis tarihi/ Date of receipt: 16/04/2021 Kabul tarihi/ Date of acceptance: 29/06/2021 \\ (C) Ordu University Faculty of Health Sciences, Department of Nursing, Turkey, Published online:08/09/2021
}

\section{ÖZ}

Amaaç: Bu çalışma, hemşirelik öğrencilerinde bilişsel esneklik ve stresin akademik başarı ile ilişsisini incelemek amacıyla yapılmıştır. Yöntem: Tanımlayıcı çalışma olarak yürütülen bu araştırmanın örneklemini iki üniversitenin hemşirelik bölümü 3. ve 4. sınıf düzeyindeki 212 öğrenci oluşturmuştur. Araştırma verileri online ortamda, Tanıtııı Bilgi Formu, Hemşirelik Öğrencileri Algılanan Stres Ölçeği ve Bilişsel Esneklik Ölçeği kullanılarak toplanmıştır.

Bulgular: Hemşirelik öğrencilerinin ödevler ve iş yükünden kaynaklanan stres puan ortalamaları, öğretim elemanı ve hemşirelerden kaynaklanan stres puan ortalamaları ve toplam algılanan stres ölçeği puan ortalamalarııın akademik başarı düzeylerine göre anlamlı farklılık gösterdiği saptanmıştır. Bilişsel esneklik ölçeği puan ortalamalarının akademik başarı düzeylerine göre anlamlı farklılık gösterdiği belirlenmiştir. Öğrencilerin ödevler ve iş yükünden kaynaklanan stres $(r=-0.189 ; \mathrm{p}=0.006)$, ortamdan kaynaklanan stres $(\mathrm{r}=-0.176 ; \mathrm{p}=0.010)$, akranlar ve günlük yaşamdan kaynaklanan stres $(\mathrm{r}=-0.179 ; \mathrm{p}=0.019)$ puanları ile bilişsel esneklik ortalama puanları arasında negatif yönde ve anlamlı ilişki olduğu saptanmıştır.

Sonuç: Hemşirelik öğrencilerinin akademik başarı düzeylerinin stres ve bilişsel esneklik düzeylerinden etkilendiği saptanmıştır. Hemşirelik öğrencilerinin streslerini azaltmaya yönelik destekleyici bir öğrenme ortamı hazırlanması ve öğrenmeyi motive ederek akademik başarılarının desteklenmesi önerilmektedir.

Anahtar Kelimeler: Akademik başarı, bilişsel esneklik, hemşirelik öğrencileri, stress

\section{ABSTRACT}

Objective: This study was performed to examine the relationship between cognitive flexibility and stress with academic achievement in nursing students.

Methods: The sample of the descriptive study consisted of 212 students at the 3rd and 4th grade of nursing departments of two different universities. Research data were collected online using the Introductory Information Form, the Nursing Students Perceived Stress Scale, and the Cognitive Flexibility Scale.

Results: Stress caused by homework and workload, stress caused by instructors and nurses, and perceived stress scale total scores differ significantly according to academic achievement levels in nursing student. It has been determined that the mean scores of the cognitive flexibility scale differ significantly according to the academic achievement levels. Cognitive flexibility scores and stress from homework and workload $(r=-0.189 ; \mathrm{p}=0.006)$. There was a significant negative relationship between cognitive flexibility scores and stress scores of students from homework and workload $(r=-0.189 ; p=0.006)$, stress from the environment $(r=-0.176 ; p=0.010)$, peers and daily life $(\mathrm{r}=-0.179 ; \mathrm{p}=0.019)$.

Conclusions: It has been determined that academic achievement of nursing students is affected by the levels of stress and cognitive flexibility. It is recommended to prepare a supportive learning environment to reduce the stress of nursing students and to support their academic success by motivating learning.

Keywords: Academic success, cognitive flexibility, nursing students, stress

ORCID IDs of the authors: NU: 0000-0002-9697-8227; FÜT: 0000-0001-8588-7867

Sorumlu yazar/Corresponding author: Dr. Öğr. Üyesi Neşe Uysal

Amasya Üniversitesi Sağlık Bilimleri Fakültesi, İpekköy, Amasya, TÜRKIYE

e-posta/e-mail: uysaln2007@hotmail.com

Atıf/Citation: Uysak N, Ünal Toprak F. (2021). Hemşirelik Öğrencilerinin Akademik Başarısı ile Stres ve Bilişsel Esneklik İlişkisinin Belirlenmesi.

Ordu Üniversitesi Hemşirelik Çalışmaları Dergisi, 2021, 4(2), 248-254. DOI:10.38108/ouhcd.918377 


\section{Giriş}

Hemşirelik eğitim programları teorik öğretim ve klinik uygulamayı esas alarak yürütülmektedir. Nitelikli profesyonel hemşireler yetiştirmek amaciyla yaşam boyu öğrenmeyi esas alan bu programlarda öğrencilerin mesleki ve toplumsal yaşama donanımlı şekilde hazırlanmaları açısından akademik başarı düzeyleri oldukça önemlidir. Bununla birlikte öğrencilerin akademik başarıları zihinsel faktörler, öğrenmeye olan ilgi, yeterlilik algıs1, güdülenme düzeyi, anksiyete ve stres gibi birçok faktörden etkilenmektedir (Açıksöz ve ark., 2016; Zengin ve ark., 2013; Zuffianò ve ark., 2013). Akademik başarı düzeyini etkileyen önemli faktörlerden biri olan stres sağlık alanındaki klinik ortamların doğası gereği hemşirelik öğrencileri arasında sik yaşanan bir sorundur. Hemşirelik öğrencileri klinik ortamların karmaşıklığ , iş yükü, yanlış uygulama yapma korkusu, öz güven eksikliği, hasta tepkileri, öğretim elemanlarından yeterli desteği alamama gibi durumlar nedeniyle stres yaşayabilmektedir. Uzun süreli ve kontrol edilemeyen stresin eğitimin etkinliğini azalttığ stresin sonucu olarak öğrencilerin hem profesyonel gelişimlerinin hem de sağlıklarının olumsuz yönde etkilendiği, öğrencilerin karar verme yeterliliklerinin bozulduğu ve akademik başarılarının düştüğü bildirilmiş̧ir (Karaca ark., 2015; Ribeiro ve ark., 2020; Y1ldırım ve ark., 2019; Pulıdo Martos, 2011; Taşdelen ve Zaybak, 2013).

Komplike ve değişim içerisindeki klinik ortamlara uyum sağlama, stresli durumlarla başetme, bilimsel problem çözme sürecini etkin kullanma becerileri bireylerin bilişsel esneklik düzeyleri ile yakından ilişsilidir (Bedel ve Ulubey, 2015; Altunkol, 2010; Çelikkaleli, 2014). Bilişsel esneklik, ortamdaki değişikliklere yanıt olarak stratejiler arasında değişiklik yapma veya geçiş yapma yeteneğini ifade etmektedir. Değişme olarak da adlandırılan bilişsel esneklik, bireye değişen kurallara, kriterlere veya görevlere dayalı olarak davranışlarını esnek bir şekilde değiştirme ve bilişsel stratejileri uyarlama yeteneği sağlamaktadır. Bilişsel esneklikte, farklılaşma ve entegrasyon olmak üzere bilişsel sürecin farklı alanları rol oynamaktadır. Farklılaşma, çeşitli boyutları tanıma, değerlendirme ve bir perspektif oluşturma yeteneğini, entegrasyon ise, bu çeşitli boyutlar arasındaki bağlantıları kavrama yeteneğini ifade etmektedir. Bu nedenle, bilişsel esneklik bir bireyin bağlamsal ve durumsal kısıtlamalara uyum sağlama yeteneğinin bir göstergesi olarak da kullanılmaktadır (Goldfarb ve ark, 2017; Plessow ve ark., 2012). Bilişsel esneklik düzeyi yüksek olan bireylerin, problemlerin çözümüne yönelik tutumlarının daha olumlu olduğu, karşılaştıkları sorunlara farklı çözüm yolları bulduğu ve değişen durumlara kolay uyum sağladığı belirtilmiştir. Ayrıca bilişsel esnekliğin akademik, sosyal ve duygusal yetkinliği artırdığı saptanmıştır (Bedel ve Ulubey, 2015; Altunkol, 2010; Çelikkaleli, 2014).

Akut stres durumunda, beklenmedik koşullar sırasında esnek düşünme ve bilişsel stratejileri uyarlama yeteneği olumsuz etkilenmektedir. İnsanın yeni veya beklenmedik koşullar sırasında esnek bir şekilde düşünme yeteneği olarak tanımlanan bilişsel esneklik, stres durumunda modüle edilen kritik işlevlerden biridir. Akut stres durumunda bilişsel esneklik olumsuz etkilenmekte ve değişen durumlara uygun davranabilme yeteneği bozulmaktadir (Plessow ve ark., 2012). Literatürde bilişsel esnekliğin anksiyete, depresyon gibi psikolojik sorunları azalttığı, stresle başetmeyi kolaylaştırdı $\breve{g}_{1}$ belirtilmektedir. Hemşirelik öğrencilerine stresli ve komplike durumlar karşısında yoğun bilgiyi kullanma, kısa sürede klinik kararlar alabilme ve karşılaşabilecekleri problemleri çözme becerisi kazandırmak oldukça önemlidir (Van der Wath and Du Tait, 2015; Aliakbari ark., 2015; Goldfarb ve ark, 2017). Literatürde öğrencilerin akademik başarıları üzerinde öz yeterlilik, stres, güdülenme, öğrenme stratejileri gibi faktörlerin etkisi incelenmiş olup, hemşirelik öğrencilerinde stres ve bilişsel esnekliğin akademik başarı düzeyleri ile birlikte değerlendirildiği sınırlı sayıda çalışma bulunmaktadır (Bedel ve Ulubey, 2015; Doğan Laçin ve Yalçın, 2019; Karaca ve ark., 2017).

$\mathrm{Bu}$ çalışma, hemşirelik öğrencilerinde bilişsel esneklik ve stresin akademik başarı ile ilişsisini incelemek amacıyla yapılmıştır.

\section{Gereç ve Yöntem \\ Araştırma Tipi}

$\mathrm{Bu}$ araştırma tanımlayıcı tipte yürütülmüş̧ür.

Projenin Evren ve Örneklemi

Araştırmanın evrenini, Amasya Üniversitesi Sağlık Bilimleri Fakültesi ve Bolu Abant İzzet Baysal Üniversitesi Sağlık Bilimleri Fakültesi Hemşirelik Bölümü öğrencileri oluşturmuştur. Pandemi nedeniyle araştırmanın yapıldığı üniversitelerde klinik ve teorik öğretim uzaktan eğitim yöntemi ile yürütülmektedir. $\mathrm{Bu}$ nedenle klinik deneyimi olmayan 1. ve 2. sinıf öğrencileri araştırmaya dahil edilememiş ve araştırmanın örneklemini 3. ve 4. sınıf hemşirelik öğrencileri 
oluşturmuştur $(\mathrm{n}=550)$. Araştırmada örneklem seçimine gidilmemiş olup, evrenin tamamına ulaşılması hedeflenmiştir. Ancak online ortamda gönderilen davetlere katılmaya onam vererek anketleri dolduran 212 öğrenci çalışmaya dahil edilmiştir.

\section{Veri Toplama Araçları}

Araştırma verileri Tanıtıcı Bilgi Formu, Hemşirelik Öğrencileri Algılanan Stres Ölçeği ve Bilişsel Esneklik Ölçeği kullanılarak toplanmıştır.

Tanıtıcı Bilgi Formu: Form ögrencilerin tanıtıcı bilgilerine (yaş, cinsiyet, sınıf düzeyi, akademik ortalamaları) yönelik 4 sorudan oluşmaktadır.

Hemşirelik Öğrencileri Algılanan Stres Ölçeği: Sheu ve ark. tarafından (2002) geliştirilen ve 29 maddeden oluşan Hemşirelik Öğrencileri Algılanan Stres Ölçeği "4- Benim için çok stres verici, 0- Benim için stres verici değil”" olmak üzere beşli likert tipindedir. Ölçek, "hastaya bakım verirken yaşanan stres" "mesleki bilgi ve beceri eksikliğinden kaynaklanan stres", "hemşirelerden ve ögretim elemanlarından kaynaklanan stres", "akranlardan ve günlük yaşamdan kaynaklanan stres" "ortamdan kaynaklanan stres" ve "ödevlerden ve iş yükünden kaynaklanan stres" olmak üzere 6 alt boyuttan oluşmaktadır. Ölçeğin toplam puanı 0-116 arasında değişmektedir. Ölçekten alınan yüksek puanlar, stres derecesinin fazlalığını göstermektedir. Ölçeğin Türkçe geçerlilik ve güvenilirlik çalışması Karaca ve ark. (2015) tarafindan yapılmıştır Ölçeğin Türkçe versiyonunun cronbach alfa katsayıs 0.93 olarak saptanmıştır (Sheu ve ark., 2002; Karaca ve ark., 2015). Bu çalışmada ölçeğin cronbach alfa katsayısı 0.95 olarak bulunmuştur.

Bilişsel Esneklik Ölçeği: Bilişsel Esneklik Ölçeği, kişinin bilişsel esneklik düzeyini belirlemek amaciyla üniversite öğrencileri için geliştirilmiştir. Martin ve Rubin (1995) tarafından geliştirilen ölçek, bilişsel esnekliğin üç boyutu olan isteklilik, farkındalık ve öz yeterlilik boyutları kullanılarak düzenlenmiş olup, 12 maddeden oluşmaktadır. Ölçeğin Türkçe geçerlilik güvenilirlik çalışması Altunkol (2011) tarafindan yapılmıştır. Ölçek toplam puanı her maddeye verilen yanıtların toplanmasıyla elde edilmektedir. Ölçekten alınan yüksek puanlar bilişsel esneklik düzeyinin yüksek olduğunu, düşük puanlar bilişsel esneklik seviyesinin düşük olduğunu göstermektedir. Ölçeğin Türkçe geçerlilik güvenilirlik çalışmasında cronbach alfa katsayısının 0.81 olduğu bulunmuştur (Altunkol, 2011). Bu çalışmada ölçeğin cronbach alfa katsayısı 0.83 olarak bulunmuştur.

\section{Verilerin toplanması}

Araştırma verileri 03.11.2020- 08.01.2021 tarihleri arasında Amasya Üniversitesi Sağlık Bilimleri Fakültesi ve Bolu Abant İzzet Baysal Üniversitesi Sağlık Bilimleri Fakültesi Hemşirelik bölümü 3. ve 4. sınıf düzeyindeki öğrenciler ile yürütülmüştür. Uzaktan eğitim süreci nedeniyle araştırma verileri online ortamda toplanmıştır. Anket formları öğrencilere, öğrenci bilgi sisteminden ulaşılan e-posta adreslerinden ve sosyal medya kanalları aracılığg ile iletilmiştir.

\section{Araştırmanın Etik Boyutu}

Araştırmanın yapıldığı fakültelerin dekanlıklarından yazılı izin alınmıştır. Araştırmanın etik açidan uygunluğu için Klinik Olmayan Araştırmalar Etik Kurulu'ndan izin alınmıştır (08.10.2020 tarih ve no:113). Veri toplama işlemi öncesinde öğrencilere araştırmanın amacı, veri toplama süreci ve araştırmaya katılımın gönüllülük esasına dayalı olduğu bildirilmiştir. Araştırmaya katılmaya onam veren öğrenciler çalışmaya dahil edilmiştir. Araştırma Helsinki Deklarasyonu prensiplerine uygun yürütülmüştür.

\section{Verilerin Değerlendirilmesi}

Araştırma verileri Statistical Package for Social Sience (SPSS) 21 program 1 kullanılarak değerlendirilmiştir. Tanımlayıcı veriler sayı, yüzde, ortalama ve ortanca değerler ile özetlenmiştir. Öğrencilerin akademik başarı düzeyleri ile algılanan stres ve bilişsel esneklik düzeyleri arasındaki karşılaştırmalarda kruskal wallis testi, tek yönlü varyans analizi kullanılmıştır. Bilişsel esneklik ve algılanan stres düzeyleri arasındaki ilişkilerin değerlendirilmesinde pearson korelasyon analizi kullanılmıştır. İstatistiksel anlamlılık değeri $\mathrm{p}<0.05$ olarak kabul edilmiştir.

\section{Bulgular}

Araştırmaya katılan hemşirelik öğrencilerinin yaş ortalaması $21.55 \pm 2.01$ 'dir. Öğrencilerin $\% 86.8$ 'i kadın, \%13.2'si erkek, \%55.2'si 3. sınıf, \%44,8'i 4. sınıf düzeyindedir. Öğrencilerin akademik başarı ortalamaları sirasiyla 2.00-2.49 (\%16), 2.50-2.99 (\%50) ve 3.00-3.49 (\%34)'dür.

Tabloda belirtilmemekle birlikte öğrencilerin algılanan stres ölçeğinden aldıkları puan ortalamaları; mesleki bilgi ve beceri eksikliğinden kaynaklanan stres $(8.18 \pm 2.63)$, hastaya bakım verirken yaşanan stres $(23.08 \pm 5.52)$, ödevler ve iş yükünden kaynaklanan stres (14.79 \pm 3.84$)$, öğretim elemanı ve hemşirelerden kaynaklanan stres $(16.71 \pm 5.00)$, ortamdan kaynaklanan stres 
(8.48 2.67$)$, toplam algılanan stres ölçeği( $82.26 \pm 20.77)$ olarak belirlenmiştir.

Tablo 1. Öğrencilerin algıladıkları stres düzeyleri ile akademik başarı düzeylerinin karşılaştırılması

\begin{tabular}{|c|c|c|c|c|c|c|c|}
\hline \multirow[b]{2}{*}{$\begin{array}{l}\text { Akademik } \\
\text { Ortalamalar }\end{array}$} & \multicolumn{7}{|c|}{ Hemşirelik Öğrencilerinde Algılanan Stres Ölçeği } \\
\hline & $\begin{array}{l}\text { Mesleki bilgi } \\
\text { ve beceri } \\
\text { eksikliğinden } \\
\text { kaynaklanan } \\
\text { stres }\end{array}$ & $\begin{array}{l}\text { Hastaya } \\
\text { bakım } \\
\text { verirken } \\
\text { yaşanan } \\
\text { stres }\end{array}$ & $\begin{array}{c}\text { Ödevler ve } \\
\text { iş yükünden } \\
\text { kaynaklanan } \\
\text { stres }\end{array}$ & $\begin{array}{c}\text { Öğretim } \\
\text { elemanı ve } \\
\text { hemşirelerden } \\
\text { kaynaklanan } \\
\text { stres }\end{array}$ & $\begin{array}{l}\text { Ortamdan } \\
\text { kaynaklanan } \\
\text { stres }\end{array}$ & $\begin{array}{l}\text { Akranlar ve } \\
\text { günlük } \\
\text { yaşamdan } \\
\text { kaynaklanan } \\
\text { stres }\end{array}$ & $\begin{array}{l}\text { Toplam } \\
\text { algilanan stres }\end{array}$ \\
\hline $2.00-2.49^{\mathrm{a}}$ & $\begin{array}{c}\text { Median } \\
\text { (Min-Max) } \\
9.5(2-12)\end{array}$ & $\begin{array}{c}\text { Median } \\
\text { (Min-Max) } \\
\text { 23(13-32) }\end{array}$ & $\begin{array}{c}\text { Median } \\
\text { (Min-Max) } \\
16(4-20)\end{array}$ & $\begin{array}{c}\text { Median } \\
\text { (Min-Max) } \\
18(3-24)\end{array}$ & $\begin{array}{c}\text { Median } \\
\text { (Min-Max) } \\
10(3-12)\end{array}$ & $\begin{array}{c}\text { Median } \\
\text { (Min-Max) } \\
12(3-16)\end{array}$ & $\begin{array}{c}\text { Median } \\
(\text { Min-Max ) } \\
86.5(36-116)\end{array}$ \\
\hline $2.50-2.99^{\mathrm{b}}$ & $9(1-12)$ & $24(7-32)$ & $16(5-20)$ & $18(1-24)$ & $9(2-12)$ & $12(0-16)$ & $88.5(21-116)$ \\
\hline $3.00-3.49^{\mathrm{c}}$ & $8(1-12)$ & $22(7-32)$ & $14(5-20)$ & $16(3-24)$ & $8(1-12)$ & $10.5(4-16)$ & $76(27-116)$ \\
\hline $\begin{array}{l}\text { Test } \\
\text { istatistiği* }\end{array}$ & 2.629 & 4.066 & 7.751 & 6.844 & 5.651 & 5.415 & 6.674 \\
\hline $\mathrm{p}$ & 0.269 & 0.131 & 0.021 & 0.033 & 0.059 & 0.067 & $\mathbf{0 . 0 3 6}$ \\
\hline Fark & & & b-c:0.009 & b-c:0.019 & & & b-c:0.036 \\
\hline
\end{tabular}

*Kruskal Wallis testi

Tablo 2. Öğrencilerin bilişsel esneklik düzeyleri ile akademik başarıları düzeylerinin karşılaştırılması

\begin{tabular}{lc}
\hline \multicolumn{1}{c}{ Akademik Ortalamalar } & Bilişsel Esneklik Ölçeği \\
\hline $2.00-2.49^{\mathrm{a}}$ & Ortalama standart sapma \\
$2.50-2.99^{\mathrm{b}}$ & $48.64 \pm 10.49$ \\
$3.00-3.49^{\mathrm{c}}$ & $51.65 \pm 8.22$ \\
\hline Test istatistiğ $i^{*}$ & $53.80 \pm 7.30$ \\
\hline $\mathrm{p}$ & 4.515 \\
\hline Fark & $\mathbf{0 . 0 1 2}$ \\
\hline
\end{tabular}

*Tek yönlü varyans analizi

Tablo 3. Algılanan stres ölçeği ve bilişsel esneklik ölçeği puanları arasında korelasyon analizi

\begin{tabular}{|c|c|c|c|c|c|c|c|}
\hline \multicolumn{8}{|c|}{ Hemşirelik Öğrencileri Algılanan Stres Ölçeği } \\
\hline & & $\begin{array}{l}\text { Mesleki bilgi } \\
\text { ve beceri } \\
\text { eksikliğinden } \\
\text { kaynaklanan } \\
\text { stres }\end{array}$ & $\begin{array}{c}\text { Ödevler ve } \\
\text { iş yükünden } \\
\text { kaynaklanan } \\
\text { stres }\end{array}$ & $\begin{array}{c}\text { Öğretim } \\
\text { elemanı ve } \\
\text { hemşirelerden } \\
\text { kaynaklanan } \\
\text { stres }\end{array}$ & $\begin{array}{c}\text { Ortamdan } \\
\text { kaynaklanan } \\
\text { stres }\end{array}$ & $\begin{array}{l}\text { Akranlar ve } \\
\text { günlük } \\
\text { yaşamdan } \\
\text { kaynaklanan } \\
\text { stres }\end{array}$ & $\begin{array}{c}\text { Toplam } \\
\text { algilanan } \\
\text { stres }\end{array}$ \\
\hline \multirow{2}{*}{$\begin{array}{l}\text { Bilişsel } \\
\text { Esneklik } \\
\text { Ölçeği }\end{array}$} & $\mathrm{r}$ & -0.117 & -0.189 & -0.052 & -0.176 & -0.179 & -0.153 \\
\hline & $\mathrm{p}$ & 0.089 & 0.006 & 0.455 & 0.010 & 0.019 & 0.026 \\
\hline
\end{tabular}

r: pearson korelasyon analizi 
Öğrencilerin bilişsel esneklik ölçeğinden aldıkları puan ortalamaları ise $47.47 \pm 6.16$ ' dır.

Öğrencilerin akademik başarı düzeyleri ile algıladıkları stres düzeyleri ortalama puanlarının karşılaştırıldığ 1 veriler Tablo 1'de belirtilmiştir. Ödevler ve iş yükünden kaynaklanan stres, öğretim elemanı ve hemşirelerden kaynaklanan stres ve algılanan stres ölçeği toplam puan ortalamalarının akademik başarı düzeylerine göre anlamlı farklılık gösterdiği saptanmıştır. Akademik başarı düzeyi 2.00-2.99 arasında olan öğrencilerin "ödevler ve iş yükünden kaynaklanan stres", "öğretim elemanı ve hemşirelerden kaynaklanan stres" ve "toplam algılanan stres ölçeği” puan ortalamasının akademik başarı düzeyi 3.00-3.49 arasında olan öğrencilerden istatistiksel olarak anlamlı şekilde yüksek olduğu saptanmıştır $(\mathrm{p}<0.05)$.

Öğrencilerin akademik başarı düzeyleri ile bilişsel esneklik ölçeği puan ortalamalarının karşılaştırıldığı veriler Tablo 2'de sunulmuştur. Bilişsel esneklik ölçeği puan ortalamalarının akademik başarı düzeylerine göre anlamlı farklılık gösterdiği saptanmıştır. Akademik başarı düzeyi 2.50-2.99 olan öğrencilerin bilişsel esneklik ortalama puanlarının akademik başarı düzeyi 3.003.49 arasında olan öğrencilerden anlamlı şekilde daha düşük olduğu saptanmıştır $(\mathrm{p}<0.05)$.

Bilişsel esneklik puanlarının ödevler ve iş yükünden kaynaklanan stres $(r=-0.189, p=0.006)$; ortamdan kaynaklanan stres $(r=-0.176, p=0.010)$; akranlar ve günlük yaşamdan kaynaklanan stres $(\mathrm{r}=$ $-0.179, \mathrm{p}=0.019)$ ve toplam algilanan stres $(\mathrm{r}=$ $0.153, \mathrm{p}=0.026$ ) puanları ile negatif yönde anlamlı bir ilişkisi olduğu saptanmıştır.

\section{Tartışma}

Hemşirelik öğrencileri, lisans eğitim ve öğretim süreçlerinde profesyonel kimlik gelişimlerinin olumsuz etkilenmesine ve bireysel sağliklarının bozulmasına neden olabilecek çok fazla stresöre maruz kalabilmektedirler (Karaca ark., 2015; Ribeiro ve ark., 2020; Y1ldırım ve ark., 2019). Uzun süre yaşanan ve kontrol edilemeyen stres durumu öğrencilerin bilişsel esneklik ve karar verme yeterliliklerini bozarak akademik başarılarının düşmesine ve sağlık sorunlarının oluşmasına neden olabilmektedir (Turan ark., 2019; Karaca ark., 2015). Araştırmalar, hemşirelik ve sağlık alanındaki diğer öğrencilerin lisans eğitimi süresince önemli psikolojik sıkıntı ve stres yaşadıklarını ve normal popülasyonla karşılaştırıldığında önemli ölçüde daha yüksek stres seviyelerine sahip olduklarını göstermiştir (Ranasinghe ark., 2017; Joseph ark.,
2015). Çalışmamızda öğrencilerin akademik başarı düzeyleri ile algıladıkları stres düzeyleri karşılaştırıldığında; ödevler ve iş yükünden kaynaklanan stres, öğretim elemanı ve hemşirelerden kaynaklanan stres ve toplam algılanan stres ölçeği puan ortalamalarının akademik başarı düzeylerine göre anlamlı farklılık gösterdiği saptanmıştır. Duari (2012)'nin öğrencilerle yaptığı çalışmada akademik başarı ile stres düzeyleri arasında ilişkinin negatif yönde olduğu saptanmıştır. Khanehkeshi (2011)'nin çalışmasında akademik performans ile akademik stres arasında negatif yönde anlamlı ilişki olduğu saptanmıştır (Khanehkeshi, 2011). Stres, hemşirelik öğrencilerinin gerek klinik başarı durumunu gerekse akademik başarılarını çeşitli düzeylerde etkilemektedir.

Öğrencilerinin yaşadıkları farklı stresörlere karşı adaptasyon sağlaması, karşılaştıkları problemlere yönelik alternatif yollar bulabilmesi ve kendini yeterli hissetmesi bilişsel esnekliği beraberinde gerektirmektedir (Çelikkaleli, 2014). Bilişsel esneklik, bireylerin baş etme mekanizmaları üzerinde rol oynayan önemli bir özelliktir (Demirtaş, 2019; Dennis ve Vander-Wal, 2010). Johnson (2016)'ın yaptığı çalışmada, bilişsel esneklik ile problem odaklı baş etme arasında pozitif yönlü bir ilişki olduğu belirlenmiştir. Dennis ve Vander-Wal (2010)'un yaptıkları çalışmaya göre, bilişsel esneklik düzeyi arttıkça problem odaklı başa çıkma stratejilerinin kullanımı artmakta, olumlu odaklanma ve sosyal destek arama daha fazla yaşanmaktadır. Tüm bu yetkinliklerin bireylerin mental ve bilişsel sağ lı̆̆ını arttırdığ (Buğa ve ark., 2018; Asıcı ve İkiz, 2015). Hemşirelikte bilimsel sorun çözme yöntemi olan hemşirelik sürecinin kullanımında, hemşirelerin bilişsel esnekliklerinin yüksek olması oldukça önemlidir. Çalışmamızda bilişsel esneklik ölçeği puan ortalamalarının akademik başarı düzeylerine göre anlamlı farklılık gösterdiği saptanmıştır. Çalışmamıza benzer olarak Çelikkaleli (2014)'nin çalışmasında, öğrencilerin akademik başarı düzeyleri ile bilişsel esneklik düzeyleri arasında anlamlı bir ilişki olduğu bulunmuştur. Buğa ve ark. (2018), Kercood ve ark. (2017), Doğan Laçin ve Yalçın (2018) lisans öğrencileri ile yaptıkları çalışmada, öğrencilerin bilişsel esneklik düzeylerinin yüksek olduğunu, öğrencilerin başarı düzeyi arttıkça bilişsel esneklik puanlarının da arttığını belirtmiştir. Bilişsel esneklik düzeyi yüksek olan kişilerin öz-güvenlerinin yüksek olduğu, sorunları çözmek için farklı yollar bulma becerisinin 
yüksek olduğu düşünüldüğünde akademik alanda da başarılı olmaları kaçınılmaz bir sonuçtur.

Stres bireyler açısından sorun oluşturan ve sorunlara yönelik problem çözme becerisini etkileyen bir durumdur. Bireylerin stresle baş etme becerileri yüksek ise bilişsel olarak daha esnek oldukları düşünülmekte ve stresle etkili bir biçimde baş etmeleri beklenmektedir (Doğan Laçin ve Yalçın, 2019). Çalışmamızda bilişsel esneklik puanları ile ödevler ve iş yükünden kaynaklanan stres, ortamdan kaynaklanan stres, akranlar ve günlük yaşamdan kaynaklanan stres arasında negatif yönde anlamlı ilişki bulunduğu saptanmıştır. Çalışmamıza benzer şekilde Altunkol'un yaptığ çalışmada öğrencilerin bilişsel esneklik düzeyleri ile algıladıkları stres düzeyleri arasında negatif yönlü zayıf bir korelasyon olduğu belirlenmiştir (Altunkol, 2011). Bu çalışma sonucunda bilişsel esneklik düzeyi yüksek olan bireylerin stres düzeylerinin daha düşük olduğu belirlenmiştir. Bilişsel esneklik düzeyleri yüksek olan öğrencilerin sorunlara yönelik farklı alternatifler veya çözümler üretebilmesi bu durumun nedeni olabilir.

Literatürde bilişsel esneklik düzeyinin deneyimle birlikte arttığı, yaşam sürecinde gelişen problemlere farklı çözüm yolları aramanın, uyum sağlayabilmek için çaba sarf etmenin, akademik sorunlarla baş etmenin, arkadaşlar-eğitimcilerklinik ortamdaki ilişkiler gibi birçok konuda mücadele etmenin önemli olduğu belirtilmektedir (Buğa ve ark., 2018, Camc1-Erdoğan, 2018, Yelpaze ve Yakar, 2019). Hemşirelik müfredatında özellikle son sinıf düzeylerinde eleştirel düşünme becerilerine ilişkin derslerin artırılması, stres düzeylerini azaltmaya yönelik uygulamaların planlanması öğrencilerin bilişsel esnekliğinin artmasına yardımcı olacaktır. Bilişsel esneklik düzeyi yüksek olan hemşirelik öğrencilerinin, yaşadıkları strese karşı daha olumlu tutum sergilemeleri ve etkili problem çözme yetenekleriyle beraber akademik başarılarının da artacağı düşünülmektedir.

\section{Sonuç ve Öneriler}

Öğrencilerin öğretim hayatındaki başarıları anksiyete, stres, motivasyon ve öz yeterlilik gibi birçok faktörlerden etkilenmektedir. Bu çalışmada hemşirelik öğrencilerinin akademik başarılarına stres ve bilişsel esnekliğin etkisi incelenmiştir. Hemşirelik öğrencilerinin eğitim süreçlerinde yaşadıkları klinik ortamın stresini azaltmaya yönelik düzenlemelerin yapılması ve öğrenmeye yönelik motivasyonu artıracak destekleyici bir öğrenme ortamının sağlanması önerilmektedir.

\section{Araştırma Sınırlılıkları}

Araştırmanın yalnızca iki devlet üniversitesindeki öğrencilerle yürütülmüş olması ve veri toplama sürecinde öğrencilerin pandemiden kaynaklı stres durumlarının dışlanamaması araştırmanın sınırlılı̆̆ıdır.

Araştırmanın Etik Yönü/ Ethics Committee Approval: Amasya Üniversitesi Girişimsel Olmayan Klinik Araştırmalar Etik Kurulundan 8 Ekim 2020 tarih ve 113 karar no ile etik kurul onayı alınmıştır.

Hakem/Peer-review: Diş hakem değerlendirmesi

Yazar Katkısi/Author Contributions: Fikir/Kavram: NU; Tasarım: NU; Veri Toplama ve/veya İşleme: NU, FÜT; Analiz ve/veya Yorum: NU, FÜT; Literatür Taraması: NU, FÜT; Makale Yazımı: NU, FÜT; Eleştirel İnceleme: NU.

Çıkar çatışması/Conflict of interest: Yazarlar arasında herhangi bir çıkar çatışması söz konusu değildir.

Finansal Destek/Financial Disclosure: Finansal destek alınmamıştır.

\section{Çalışma Literatüre Ne Kattı?}

- Hemşirelik öğrencilerinin stres düzeyleri akademik başarılarını etkilemektedir.

- Ortamdan ve iş yükünden kaynaklanan stres bilişsel esneklik düzeylerini olumsuz etkilemektedir.

- Hemşirelik eğitiminde stresi azaltmaya yönelik uygulamalar akademik başarı ve bilişsel esneklik düzeylerini olumlu etkileyerek öğrenme sürecine destek sağlayabilir.

\section{Kaynaklar}

Açıksöz S, Uzun Ş, Arslan F. (2016). Hemşirelik öğrencilerinde öz yeterlilik algısı ile klinik uygulamaya ilişkin kaygı ve stres durumu arasındaki ilişkinin incelenmesi. Gülhane Tıp Dergisi, 58, 129135 .

Aliakbari F, Parvin N, Heidari M, Haghani F. (2015). Learning theories application in nursing education. Journal Education Health Promotion, 4, 2.

Altunkol, F. (2011). Üniversite öğrencilerinin bilişsel esneklikleri ile algılanan stres düzeyleri arasındaki ilişkinin incelenmesi. Çukurova Üniversitesi Sosyal Bilimler Enstitüsü, Adana.

Bedel A, Ulubey E. (2015). Ergenlerde başa çıkma stratejilerini açıklamada bilişsel esnekliğin rolü. Elektronik Sosyal Bilimler Dergisi, 14(55), 291-300. 
Buğa A, Özkamalı E, Altunkol F, Çekiç A. (2018). Üniversite öğrencilerinin bilişsel esneklik düzeylerine göre sosyal problem çözme tarzlarının incelenmesi. Gaziantep Üniversitesi Eğitim Bilimleri Dergisi, 2(1), 48-58.

Camc1 Erdoğan, S. (2018). Üstün zekalılar öğretmenliği adaylarinin bilişsel esneklik düzeylerinin incelenmesi. Celal Bayar Üniversitesi Sosyal Bilimler Dergisi, 16(3), 77-96.

Çelikkaleli Ö. (2014). Ergenlerde bilişsel esneklik ile akademik, sosyal ve duygusal yetkinlik inançları arasındaki ilişki, Eğitim ve Bilim, 39(176), 347-354.

Demirtaş AS. (2019). Üniversite öğrencilerinin stresle başa çıkma stratejileri: bilişsel esneklik ve özdüzenlemenin rolü. Social Sciences, 14(3), 447-464.

Dennis JP, Vander Wal JSV. (2010). The cognitive flexibility inventory: Instrument development and estimates of reliability and validity. Cognitive Therapy and Research, 34, 241-253.

Doğan Laçin BG, Yalçın İ. (2019). Üniversite öğrencilerinde öz-yeterlilik ve stresle başa çıkma stratejilerinin bilişsel esnekliği yordama düzeyleri. Hacettepe Üniversitesi Eğitim Fakültesi Dergisi, 34(2), 358-371.

Duari P. (2012). Importance of selfesteem among students in academic performance and coping with stress. Indian Journal of Positive Psychology, 3(4), 474.

Goldfarb EV, Froböse MI, Cools R, Phelps EA. (2017). Stress and cognitive flexibility: cortisol increases are associated with enhanced updating but impaired switching. Journal of Cognitive Neuroscience, 29, 14-24.

Joseph N, Joseph N, Panicker V, Nelliyanil M, Jindal A, Viveki R. (2015). Assessment and determinants of emotional intelligence and perceived stress among students of a medical college in south India. Indian Journal Public Health, 59, 310-3.

Karaca A, Yildirim N, Ankarali H, Acikgoz F, Akkuş D. (2015). Hemşirelik öğrencileri için algılanan stres, biyo-psiko-sosyal cevap ve stresle başetme davranışları ölçeklerinin Türkçe'ye uyarlanması. Psikiyatri Hemşireliği Dergisi, 6, 15-25.

Kercood S, Lineweaver TT, Frank CC, Fromm ED. (2017). Cognitive flexibility and its relationship to academic achievement and career choice of college students with and without attention deficit hyperactivity disorder. Journal of Postsecondary Education and Disability, 30(4), 329-44.

Khanehkeshi A. (2011). The Relationship of academic stress with aggression, depression and academic performance of college students in Iran. Journal on Educational Psychology, 5(1), 24-31.

Martin MM, Rubin RB (1995). A new measure of cognitive flexibility. Psychological Reports, 76, 623626.
Plessow F, Kiesel A, Kirschbaum C. (2012). The stressed prefrontal cortex and goal-directed behaviour: Acute psychosocial stress impairs the flexible implementation of task goals. Experimental Brain Research, 216, 397-408.

Pulıdo Martos M, Augusto Landa JM, Lopez Zafra E. (2011). Sources of stress in nursing students: a systematic review of quantitative studies. International Nursing Review, 59, 15-25.

Ranasinghe P, Wathurapatha WS, Mathangasinghe Y, Ponnamperuma G. (2017). Emotional intelligence, perceived stress and academic performance of Sri Lankan medical undergraduates. BMC Medical Education, 17, 41 .

Ribeiro FMSS, Mussi FC, Pires CGS, Silva RM, Macedo TTS, Santos CAST. (2020). Stress level among undergraduate nursing students related to the training phase and sociodemographic factors. Revista LatinoAmericana Enfermagem, 28, e3209.

Sheu S, Lin HS, Hwang SL. (2002). Perceived stress and physio-psycho-social status of nursing students during their initial period of clinical practice: the effect of coping behaviors. International Journal of Nursing Studies, 39, 165-75.

Taşdelen S, Zaybak A. (2013). Hemşirelik öğrencilerinin ilk klinik deneyim sırasındaki stres düzeylerinin incelenmesi. Florence Nightingale Hemşirelik Dergisi, 21, 101-106.

Turan N, Durgun H, Kaya H, Ertaş G, Kuvan D. (2019). Hemşirelik öğrencilerinin stres durumları ile bilişsel esneklik düzeyleri arasındaki ilişki. Hemşirelik Akademik Araştırma Dergisi, 5(1), 59-66.

Van der Wath AE, Du Toit PH. (2015). Learning end-oflife care within a constructivist model: Undergraduate nursing students' experiences. Curationis, 38(2), 1537.

Yelpaze İ, Yakar L. (2019). Üniversite öğrencilerinin yaşam doyumu ve bilişsel esnekliklerinin incelenmesi. Türk Psikolojik Danışma ve Rehberlik Dergisi, 9(54), 913-935.

Yıldırım N, Karaca A, Ankaralı H, Açıkgöz F, Akkuş D. (2016). Stress experienced by Turkish nursing students and related factors. Clinical Experimental Health Science, 6(3), 121-128.

Zengin N, Pınar R, Cil Akinci A, Yildiz H. (2013). Psychometric properties of the self-efficacy for clinical evaluation scale in Turkish nursing students. Journal of Clinical Nursing, 23, 976-984.

Zuffianò A, Alessandri G, Gerbino M, Kanacri BPL, Di Giunta L, Milioni M, Caprara GV. (2013). Academic achievement: The unique contribution of self-efficacy beliefs in self-regulated learning beyond intelligence, personality traits, and self-esteem. Learning and Individual Differences, 23, 158-162. 